\title{
REST wt Allele
}

National Cancer Institute

\section{Source}

National Cancer Institute. REST wt Allele. NCI Thesaurus. Code C122745.

Human REST wild-type allele is located in the vicinity of $4 q 12$ and is approximately $28 \mathrm{~kb}$ in length. This allele, which encodes RE1-silencing transcription factor protein, plays a role in repressing neuronal gene expression in non-neuronal tissues. 